\title{
Chromosomal Characteristics of the Tropical Oyster, Crassostrea belcheri Sowerby, 1871 (Ostreoida, Ostreidae) by Conventional and Ag-NOR Banding Techniques
}

\author{
Supatcha Chooseangjaew ${ }^{1,2,3}$, Suwat Tanyaros ${ }^{3}$, Nuntiya Maneechot ${ }^{4}$, \\ Phichaya Buasriyot ${ }^{1}$, Nuntaporn Getlekha ${ }^{2}$ and Alongklod Tanomtong ${ }^{1,2 *}$ \\ ${ }^{1}$ Research Group on Toxic Substances in Livestock and Aquatic Animals, Khon Kaen University, \\ Khon Kaen 40002, Thailand \\ ${ }^{2}$ Department of Biology, Faculty of Science, Khon Kaen University, Khon Kaen 40002, Thailand \\ ${ }^{3}$ Marine Shellfish Breeding Research Unit, Department of Marine Science, Faculty of Science and Fisheries \\ Technology, Rajamangala University of Technology Srivijaya, Trang Campus, Trang 92150, Thailand \\ ${ }^{4}$ Program in Biology, Department of Fundamental Science, Faculty of Science and Technology, Surindra \\ Rajabhat University, Surin 32000, Thailand
}

Received July 7, 2015; accepted November 3, 2015

\begin{abstract}
Summary Chromosome preparation from gill tissue of the tropical oyster (Crassostera belcheri Sowerby, 1871) collected from an oyster farm in Kantang District, Trang Province, southern Thailand was studied by conventional staining and Ag-NOR baining techniques. The result revealed that the diploid chromosome number is $2 n=20$ and the fundamental number (NF) is 40 . The karyotype has revealed 10 large metacentric and 10 medium metacentric chromosomes. One pair of nucleolar organizer regions (NORs) was apparent on the short arm telomeric region of chromosome pair 10. Basic information on the cytogenetics of the $C$. belcheri may be useful for future studies on interspecific hybridization and polyploidy. The karyotype formula of $C$. belcheri is as follows:
\end{abstract}

$2 n$ (diploid) $20=\mathrm{L}_{10}^{\mathrm{m}}+\mathrm{M}_{10}^{\mathrm{m}}$

Key words Crassostrea belcheri, Karyotype, Chromosome, Nucleolar organizer region.

Oysters are marine bivalve mollusks inhabiting nearshore areas, shallow waters, bays, mangroves and estuaries. They have been widely distributed throughout the tropical and subtropical regions (Hedgecock 1995). Nine species of oysters belonging to the family Ostreidae were found in Thai waters (Yoosukh and Duangdee 1999). Three species of oyster in Thailand are cultured commercially as Crassostrea belcheri, C. iredalei and Saccostrea cucullata (Jarayabhand and Thavornyutikarn 1995, Klinbunga et al. 2005).

The tropical oyster (Crassostrea belcheri Sowerby, 1871 ) is one of the most important commercial bivalves in Thailand. The culture of this oyster has been practiced for several decades along the coast of Thailand. The commom name for this oyster in Thai is "Hoy Ta krom Kram Khao" because the color of its adductor muscle scars is white (Fig. 1) (Visootiviseth et al. 1998). This oyster inhabits mangroves and estuaries in southern Thailand, both the Gulf of Thailand and the Andaman Sea, and Surathanee, Songkhla, Pangnga and Ranong provinces (Klinbunga et al. 2005). This species has high

\footnotetext{
* Corresponding author, e-mail: tanomtong@hotmail.com DOI: $10.1508 /$ cytologia.82.3
}

market demand in comparision with other oyster species (Suzana et al. 2011).

The morphological classification of oysters is difficult, which is attributable to the oyster shell typically acting as the substrate for attachment of plastic. The plastic affects the shell's characteristic development (Lam and Morton 2003) and leads to the loss of morphological information (Wang et al. 2004). Recently, cytogenetic studies concerning the number, size, and characteristics of chromosomes and gross morphology of the oyster have been conducted for taxonomic identification (Leitao et al. 1999b). The karyotype information is clearly useful for genetics research in Mytilus edulis aquaculture (Moynihan and Mahon 1983), taxonomic relationships in Ostrea angasi (Li and Havenhand 1997) and distribution of mangrove oysters (Lapegue et al. 2002). The chromosomal characteristics of oysters recorded in the family Ostreidae are a common diploid number $(2 n=20)$, which is a low haploid number, small size, and similarity in size and arm ratio of the chromosome (Wang et al. 2004). The karyotype formulas of the oysters in this family mainly consisted of metacentric and submetacentric chromosomes (Table 1).

Several banding techniques have been successfully 

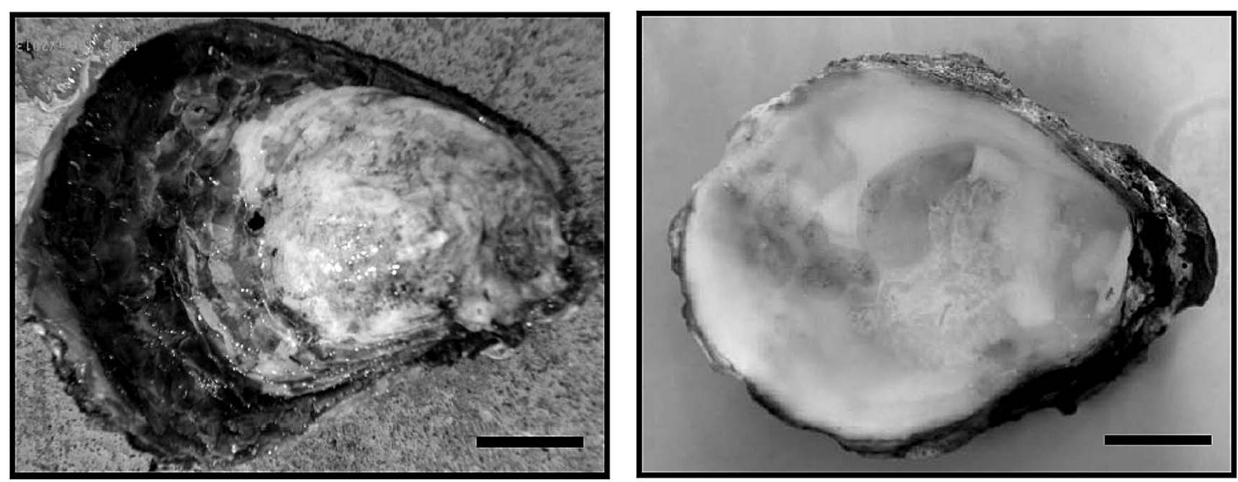

Fig. 1. General characteristics of the tropical oyster, Crassostrea belcheri (scale bars $=3 \mathrm{~cm}$ ).

Table 1. Review of oyster cytogenetic reports in the family Ostreidae.

\begin{tabular}{|c|c|c|c|c|c|}
\hline Species & $2 n$ & NF & Karyotype formula & NORs banded & Reference \\
\hline Crassostrea angulata & 20 & 40 & $20 \mathrm{~m}$ & 10 & Cross et al. (2003) \\
\hline C. ariakensis & 20 & 40 & $16 m+4 s m$ & 9,10 & Thiriot-Quiévreux (2002) \\
\hline \multirow[t]{2}{*}{ C. belcheri } & 20 & 40 & $20 \mathrm{~m}$ & - & Koedprang and Wattanakul (1996) \\
\hline & 20 & 40 & $20 \mathrm{~m}$ & 10 & Present study \\
\hline C. gasar & 20 & 40 & $12 \mathrm{~m}+8 \mathrm{sm}$ & 2 & Leitao et al. (1999a) \\
\hline \multirow[t]{2}{*}{ C. gigas } & 20 & 40 & $20 \mathrm{~m}$ & 10 & Thiriot-Quiévreux and Insua (1992) \\
\hline & 20 & 40 & $20 \mathrm{~m}$ & - & Leitao et al. (1999a) \\
\hline C. rhizophorae & 20 & 40 & $12 \mathrm{~m}+8 \mathrm{sm} / \mathrm{st}$ & 3 & Lapegue et al. (2002) \\
\hline C. sikamea & 20 & 40 & $18 \mathrm{~m}+2 \mathrm{sm}$ & 10 & Leitao et al. (1999a) \\
\hline C. virginica & 20 & 40 & $16 m+4 s m$ & 1,5 & Leitao et al. (1999a) \\
\hline \multirow[t]{2}{*}{ Ostrea angasi } & 20 & 40 & $10 m+6 s m+4 s t$ & 9,10 & Li and Havenhand (1997) \\
\hline & 20 & 40 & $10 m+6 s m+4 s t$ & $4,9,10$ & Pereira et al. (2011) \\
\hline O. chilensis & 20 & 40 & $14 m+6 s m$ & 2,9 & Pereira et al. (2011) \\
\hline O. conchaphila & 20 & 40 & $12 m+8 s m$ & 5,7 & Leitao et al. (2002) \\
\hline O. denselamellosa & 20 & 40 & $14 m+6 s m$ & 3,8 & Insua and Thiriot-Quiévreux (1991) \\
\hline \multirow[t]{2}{*}{ O. edulis } & 20 & 40 & $10 \mathrm{~m}+10 \mathrm{sm}$ & 9,10 & Thiriot-Quiévreux and Insua (1992) \\
\hline & 20 & 40 & $10 \mathrm{~m}+8 \mathrm{sm}+2 \mathrm{st}$ & - & Patakine Varkonyi et al. (2013) \\
\hline O. puelchana & 20 & 40 & $8 m+10 s m+2 t$ & 2,4 & Insua and Thiriot-Quiévreux (1993) \\
\hline O. stentina & 20 & 40 & $12 \mathrm{~m}+8 \mathrm{sm}$ & - & Pereira et al. (2011) \\
\hline Saccostrea commercialis & 20 & 40 & $16 m+4 s m$ & 9,10 & Leitao et al. (1999a) \\
\hline S. cucullata & 20 & 40 & $14 m+6 s m$ & - & Thiriot-Quiévreux (2002) \\
\hline
\end{tabular}

Remarks: $2 n=$ diploid chromosome number, $\mathrm{NF}=$ fundamental number, $\mathrm{m}=$ metacentric, $\mathrm{sm}=$ submetacentric, st=subtelocentric, NORs $=$ nucleolar organizer regions and $-=$ not available.

studied in family Ostreidae, for example, C-banding ( $\mathrm{Li}$ and Havenhand 1997, Leitao et al. 2002, Cross et al. 2005, Bouilly et al. 2008, Pereira et al. 2011), G-banding (Leitao et al. 1999b), fluorochome (Cross et al. 2005), fluorescent in situ hybridization (FISH) (Xu et al. 2001, Cross et al. 2003, 2005, Wang et al. 2004, Bouilly et al. 2008, Pereira et al. 2011) and Ag-NOR chromosome staining (Li and Havenhand 1997, Leitao et al. 2002, Cross et al. 2003).

The nucleolar organizer regions (NORs) on the chromosome are the chromosomal marker. NORs consist of DNA, RNA and proteins that are located on the chromosome. Silver nitrate staining technique (Ag-NOR) is typically used to visualize NORs on the chromosome (Cross et al. 2003). NORs have been used for inferring phylogenetic relationships (Amemiya and Gold 1990). Differences in number, size and location of NORs on the chromosome can be used as the chromosome marker for polymorphisms (Cross et al. 2005). Chromosomal location of NORs in most Ostreidae was terminal on the short or long chromosome arm (Thiriot-Quiévreux 2002). In this the study, we examined the chromosome number, size, and characteristics of and conducted the first study of NOR location on C. belcheri in Thailand by the conventional staining and Ag-NOR banding techniques. Our findings will benefit the taxonomy and evolutionary relationships in cytogenetics for this species.

Materials and methods

\section{Sample collection}

Ten specimens of mature C. belcheri oysters were collected from Kantang District, Trang Province, southern Thailand. The collected oysters were cleaned and placed in a styrofoam box. The samples were then taken to the Cytogenetic Laboratory, Department of Biology, Faculty of Science, Khon Kaen University. 


\section{Chromosome preparation}

The oysters ( $c a .8-10 \mathrm{~cm}$ in shell length) were exposed to $0.1 \%$ colchicine solution for $12 \mathrm{~h}$. The oyster meat was removed from the shell and the gills were cut off. The gill tissue was prepared by cutting into small pieces and minced gently before being transferred into a centrifuge tube containing $8 \mathrm{~mL}$ of $0.075 \% \mathrm{KCl}$ hypotonic solution (Kasiroek et al. 2017). The samples were treated in the solution for 30-40 min prior to centrifuging at $1500 \mathrm{rpm}$ for $8 \mathrm{~min}$. The supernatant was siphoned out and the remaining sediment gill tissue was fixed in $8 \mathrm{~mL}$ of a freshly prepared solution (methanol:acetic acid; ratio $3: 1)$. The sample was then taken to a centrifuge three to four times until the sediment cell was cleared. The sediment cell was dropped on a clean and warm slide and air-dried (Wang et al. 2004, Khrueanet et al. 2013)

\section{Chromosome staining}

The chromosome staining was performed by conventional staining technique by soaking in $15 \%$ Giemsa's solution in phosphate buffer $\mathrm{pH} 6.8$ for $15 \mathrm{~min}$ (Leitao et al. 1999a). The sample slide was gently rinsed with fresh water, and the chromosome was counted individually under a compound microscope (Olympus, CH30, Japan). Complete 20 metaphase plates were selected to perform karyotype analysis.

The Ag-NOR banding was performed by adding two drops of gelatin and four drops of $50 \%$ silver nitrate solution on a slide sample prior to closing by a cover glass and drying at $60^{\circ} \mathrm{C}$ in a hot-air oven for $5 \mathrm{~min}$. The slide was rinsed by distilled water until the cover glass fell off (Howell and Black 1980, Sangpakdee et al. 2017).

\section{Chromosome checks}

A complete metaphase plate chromosome was counted and photographed under a compound microscope (Olympus, CH30, Japan). The length of short (Ls) and long arms (Ll) on the chromosome were measured by using the Adobe Photoshop software. Those values were used to calculate the length of total arm chromosome (LT) $(\mathrm{LT}=\mathrm{Ls}+\mathrm{Ll})$. The relative length $(\mathrm{RL})$ and centrometric index (CI) were estimated by the method according to Chaiyasut (1989). $\mathrm{CI}=(\mathrm{q} / \mathrm{p}+\mathrm{q})$ of $0.50-0.59$, $0.60-0.69,0.70-0.89$ and $0.90-0.99$ are described as metacentric, submetacentric, acrocentric and telocentric chromosomes, respectively. All values were used for karyotype and idiogram.

\section{Results and discussion}

Twenty well-characterized metaphase chromosomes from the gill tissue of each $C$. belcheri were analyzed for karyotype, and chromosomes were classified by averaged data on the chromosome size and centrometric position (Cross et al. 2003). Our study showed a diploid chromosome number of $2 n=20$ (Fig. 2). This is a common characteristic karyotype of oysters in the family Ostreidae (Thiriot-Quiévreux 2002). The result of C.belcheri with $2 n=20$ corresponds with many species of oysters in the family Ostreidae. Ten pairs of meta-
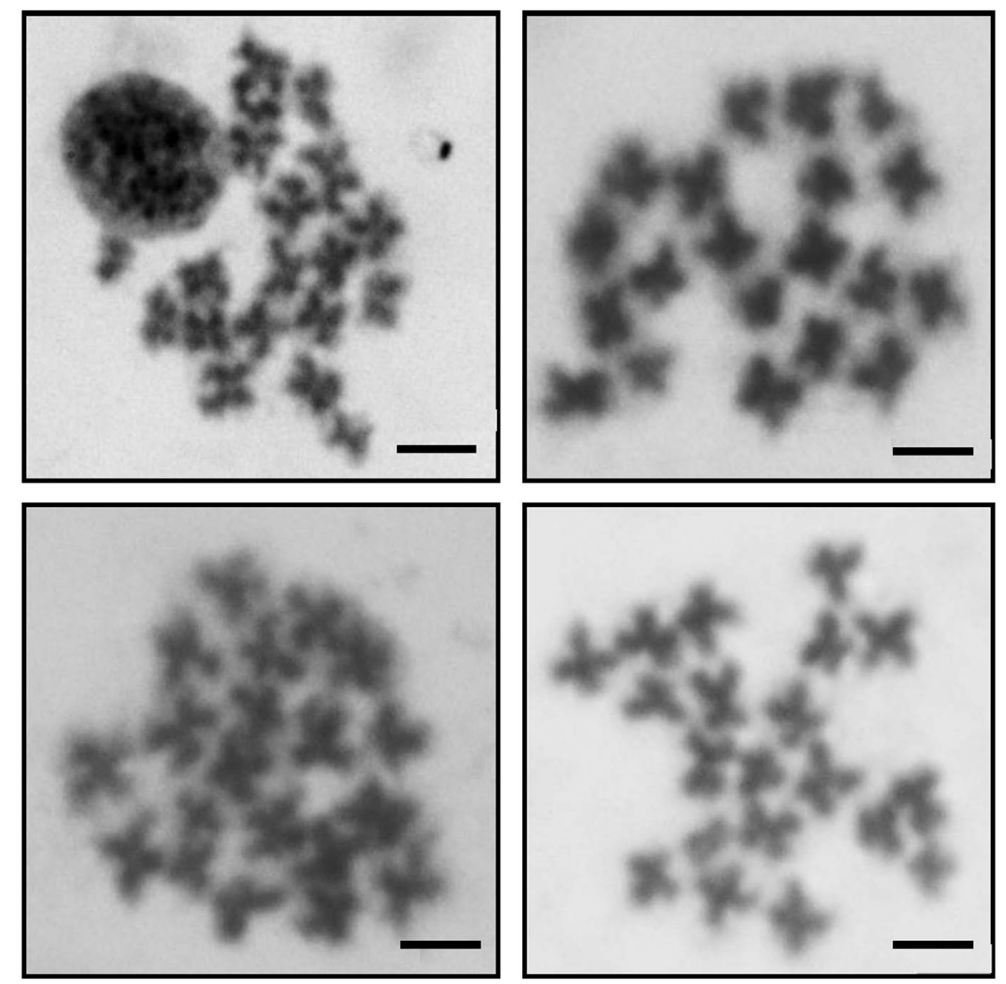

Fig. 2. Metaphase chromosome plates of the tropical oyster (Crassostrea belcheri), $2 n=20$ from Trang Province, Southern Thailand by conventional straining technique (scale bars $=5 \mu \mathrm{m}$ ). 

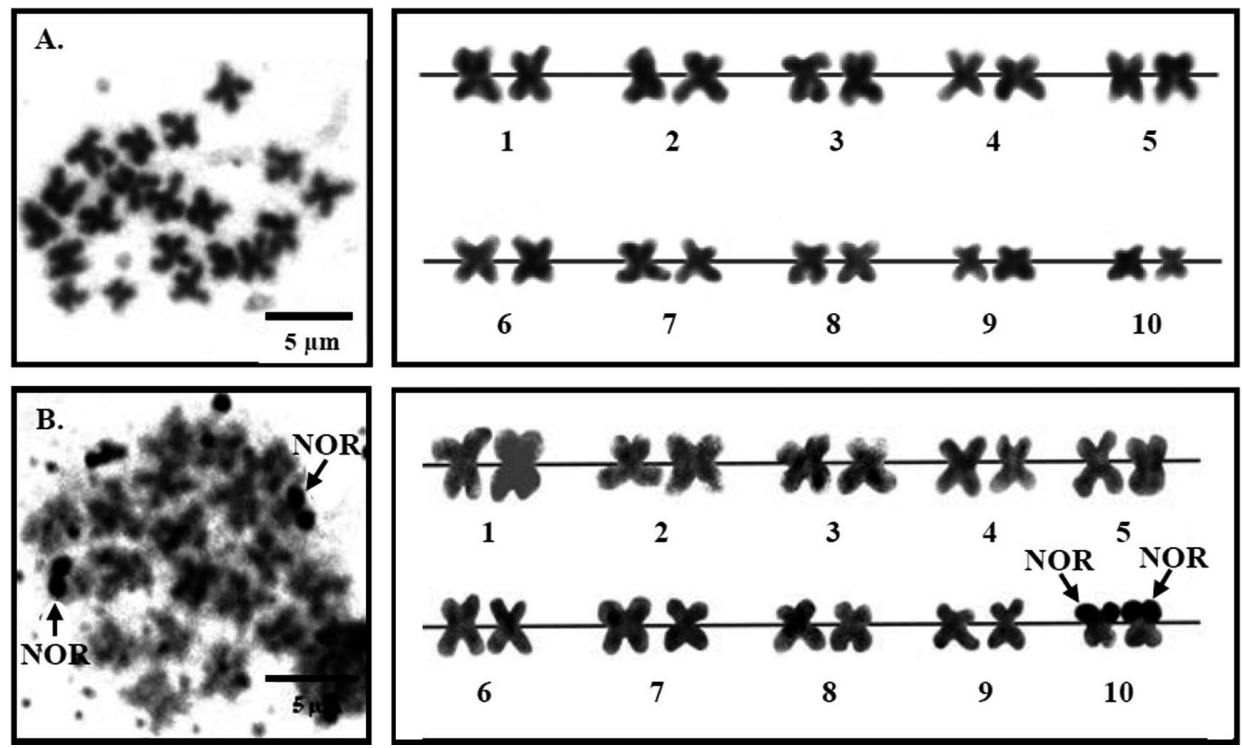

Fig. 3. Metaphase chromosome plates and karyotypes of the tropical oyster (Crassostrea belcheri), $2 n=20$ from Trang Province, Southern Thailand by conventional straining technique (A.) and Ag-NOR banding technique (B.). Arrow indicates nucleolar organizer regions (satellite chromosomes).

Table 2. Mean length of short arm chromosomes (Ls), long arm chromosomes (L1), total arm chromosomes (LT), relative length (RL), centromeric index (CI) and standard deviation (SD) of RL and CI from 20 metaphase cells of tropical oyster (Crassostrea belcheri), $2 n=20$

\begin{tabular}{|c|c|c|c|c|c|c|c|}
\hline Chro. pair & Ls & $\mathrm{Ll}$ & LT & $\mathrm{RL} \pm \mathrm{SD}$ & $\mathrm{CI} \pm \mathrm{SD}$ & Chro. size & Chro. type \\
\hline 1 & 1.571 & 1.893 & 3.464 & $0.129 \pm 0.009$ & $0.551 \pm 0.037$ & $\mathrm{~L}$ & $\mathrm{~m}$ \\
\hline 2 & 1.453 & 1.751 & 3.203 & $0.118 \pm 0.005$ & $0.548 \pm 0.029$ & $\mathrm{~L}$ & $\mathrm{~m}$ \\
\hline 3 & 1.346 & 1.670 & 3.016 & $0.111 \pm 0.004$ & $0.552 \pm 0.032$ & $\mathrm{~L}$ & $\mathrm{~m}$ \\
\hline 4 & 1.267 & 1.590 & 2.857 & $0.105 \pm 0.004$ & $0.556 \pm 0.023$ & $\mathrm{~L}$ & $\mathrm{~m}$ \\
\hline 5 & 1.246 & 1.538 & 2.784 & $0.102 \pm 0.003$ & $0.551 \pm 0.018$ & $\mathrm{~L}$ & $\mathrm{~m}$ \\
\hline 6 & 1.187 & 1.463 & 2.651 & $0.098 \pm 0.004$ & $0.552 \pm 0.021$ & M & $\mathrm{m}$ \\
\hline 7 & 1.142 & 1.392 & 2.534 & $0.093 \pm 0.004$ & $0.55 \pm 0.033$ & M & $\mathrm{m}$ \\
\hline 8 & 1.063 & 1.320 & 2.383 & $0.088 \pm 0.005$ & $0.555 \pm 0.040$ & M & $\mathrm{m}$ \\
\hline 9 & 0.989 & 1.227 & 2.216 & $0.082 \pm 0.004$ & $0.55 \pm 0.043$ & M & $\mathrm{m}$ \\
\hline $10 *$ & 0.921 & 1.096 & 2.016 & $0.075 \pm 0.007$ & $0.54 \pm 0.034$ & M & $\mathrm{m}$ \\
\hline
\end{tabular}

Remarks: *=NOR-bearing chromosome (satellite chromosome), chro.=chromosome, L=large chromosome (LT>2.739), M=medium chromosome (LT=1.731-2.739) and $\mathrm{m}=$ metacentric chromosome.

centric chromosome set in this species were reported by Koedprang and Wattanakul (1996) (Fig. 3A), similar to other species in the family Ostreidae. The fundamental number (NF, number of chromosome arms) of chromosomes in this species equaled 40 . The characteristic karyotype consisted of 20 large and 20 medium metacentric chromosomes (Table 2). Most karyotypes in the family Ostreidae consist of metacentric and submetacentric chromosomes (Pereira et al. 2011). Different numbers and positions of metacentric and submetacentric chromosome pairs in the karyotype have been reported by several authors. However, only metacentric karyotypes in $C$. belcheri were observed in the present study. This may have resulted from different geographies and technical use, as well as the concentration and duration of colchicine exposure ( $\mathrm{Li}$ and Havenhand 1997, Leitao et al. 1999a, Thiriot-Quiévreux 2002) and pericentric inversions or centrometric shifts (Ahmed 1973) which lead to intraspecific polymorphism.

The NOR banding was shown during the late inter- phase by silver nitrate staining; the silver binds to a complex of acidic protein associated with the nucleolus and nascent pre-RNA (Cross et al. 2005), and the locations of NORs consisting of more non-histone proteins than other regions are indicated by dark bands as the silver turns dark due to the protein (Khrueanet et al. 2013). Our finding revealed that only one position of NORs was located on the short arm telomeric region of chromosome pair 10 (Fig. 3B), which is similar to other oyster species in the family Ostreidae including $C$. angulate (Cross et al. 2003) and C. gigas (Leitao et al. 1999a, Thiriot-Quiévreux 2002). The NOR position on the terminals of the short or long arm chromosome has been reported, and metacentric or submetacentric chromosomes dominated in most bivalves (Thiriot-Quiévreux 2002). The oyster in the family Ostreidae can be found with 1-3 chromosome pairs with Ag-NOR positions. These chromosomal NORs can express phylogenetic relationships. A single position of NORs may have a plesiomorphic characteristic (Amemiya and Gold 1990). 


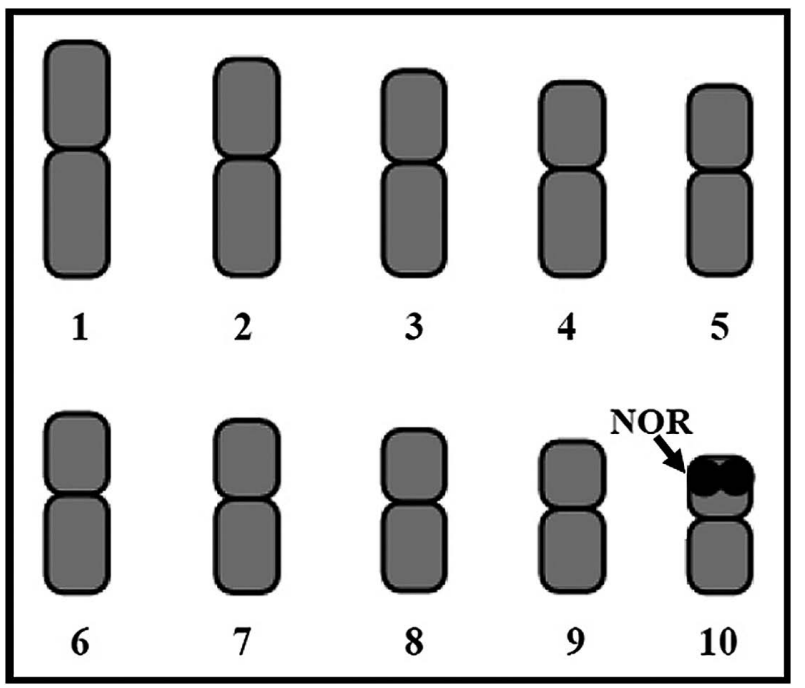

Fig. 4. Idiogram showing lengths and shapes of chromosomes of the tropical oyster (Crassostrea belcheri), $2 n=20$ by AgNOR banding technique.

In Ostreidae, such as C. gigas, $C$. rhizophorae, $C$. gasar and $C$. belcheri in this study, one position of NORs was found; these are more primitive than other oyster species (Thiriot-Quiévreux and Insua 1992). The karyotype, number and NOR location of $C$. belcheri in this study was similar to those of $C$. angulate and $C$. gigas, indicating that they are more phylogenetically close than other Ostreidae species (Leitao et al. 1999a). Furthermore, chromosomal NORs revealed the evolution relationship among species, within species and even between individuals, as have been reported by Leitao and Chaves (2008). In addition, the structure, number and morphology of NORs may be specific to a population, species or subspecies. Variations of the number and NOR location have been reported among the oyster species (Thiriot-Quiévreux and Insua 1992). NOR location corresponded with ribosomal gene location, which can identify in situ hybridization. However, Ag-NOR banding cannot reveal rDNA genes in cthe hromosome (Cross et al. 2005). In addition, NORs have been indicated by the cell metabolic activity. They can clarify the physiology of the organism. NOR activity in larvae stages higher than in juveniles has been repored in mussels (MartinezExposito et al. 1994). However, variations in number of NORs by Ag-NOR staining techniques occur because transcriptional activities of rDNA are structural changes, such as chromosome duplications, deletions, investion, fission, fusion, aneuploidy or translocations of the rDNA gene (Cross et al. 2003, Wang et al. 2004).

The chromosome lengths of 20 cells in mitotic metaphase were measured in this study. The mean short arm length (Ls), long arm length (Ll), total arm length (LT), relative length $(\mathrm{RL})$, centrimetric index $(\mathrm{CI})$, size, and type of chromosome from several species of oyster are shown in Table 2. The idiogram of the C. belcheri from Ag-NOR banding is shown in Fig. 4. The karyotype for- mula of $C$. belcheri is as follows:

$$
2 n \text { (diploid) } 20=\mathrm{L}_{10}^{\mathrm{m}}+\mathrm{M}_{10}^{\mathrm{m}}
$$

\section{Acknowledgements}

This study was supported by the Research Group on Toxic Substances in Livestock and Aquatic Animals, Khon Kaen University and Faculty of Science and Fishries Technology, Rajamangala University of Technology Srivijaya.

\section{References}

Ahmed, M. 1973. Cytogenetics of oysters. Cytologia 38: 337-346. Amemiya, C. T. and Gold, J. R. 1990. Cytogenetic studies in North American minnows (Cyprinidae): Chromosomal NOR phenotypes of 12 species, with comments on cytosystematic relationships among 50 species. Hereditas 112: 231-247.

Bouilly, K., Chaves, R., Leitao, A., Benabdelmouna, A. and GuedesPinto, H. 2008. Chromosomal organization of simple sequence repeats in the Pacific oyster (Crassostrea gigas): (GGAT) (4), (GT)(7) and (TA)(10) chromosome patterns. J. Genet. 87: $119-125$.

Chaiyasut, K. 1989. Cytogenetics and Cytotaxonomy of the Family Zephyranthes. Department of Botany, Faculty of Science, Chulalongkorn University, Bangkok.

Cross, I., Diaz, E., Sanchez, I. and Rebordinos, L. 2005. Molecular and cytogenetic characterization of Crassostrea angulata chromosomes. Aquaculture 247: 135-144.

Cross, I., Vega, L. and Rebordinos, L. 2003. Nucleolar organizing regions in Crassostrea angulata: Chromosomal location and polymorphism. Genetica 119: 65-74.

Hedgecock, D. 1995. The cupped oyster and the Pacific oyster. In: Thorpe, J., Gall, G., Lannan, J. and Nash, C. (eds.). Conservation of Fish and Shellfish Resources: Managing Diversity. Academic Press, London. pp. 115-137.

Howell, W. M. and Black, D. A. 1980. Controlled silver-staining of nucleolus organizer regions with a protective colloidal developer: A 1-step method. Experientia 36: 1014-1015.

Insua, A. and Thiriot-Quiévreux, C. 1991. The characterization of Ostrea denselamellosa (Mollusca, Bivalvia) chromosomes: Karyotype, constitutive heterochromatin and nucleolus organizer regions. Aquaculture 97: 317-325.

Insua, A. and Thiriot-Quiévreux, C. 1993. Karyotype and nucleolus organizer regions in Ostrea puelchana (Bivalvia: Ostreidae). Veliger 36: 215-219.

Jarayabhand, P. and Thavornyutikarn, M. 1995. Realized heritability estimation on growth rate of oyster, Saccostrea cucullata Born, 1778. Aquaculture 138: 111-118.

Kasiroek, W., Indananda, C., Luangoon, N., Pinthong, K., Supiwong, W. and Tanomtong, A. 2017. First chromosome analysis of the humpback cardinalfish, Fibramia lateralis (Perciformes, Apogonidae). Cytologia 82: 9-15.

Khrueanet, W., Supiwong, W., Tumpeesuwan, C., Tumpeesuwan, S., Pinthong, K. and Tanomtong, A. 2013. First chromosome analysis and localization of the nucleolar organizer region of land snail, Sarika resplendens (Stylommatophora, Ariophantidae) in Thailand. Cytologia 78: 213-222.

Klinbunga, S., Khamnamtong, B., Puanglarp, N., Jarayabhand, P., Yoosukh, W. and Menasveta, P. 2005. Molecular taxonomy of cupped oysters (Crassostrea, Saccostrea, and Striostrea) in Thailand based on COI, 16S and 18S rDNA polymorphism. Mar. Biotechnol. 7: 306-317.

Koedprang, W. and Wattanakul, W. 1996. Study on karyotypes of 
three species of Ostreidae oysters, Crassostrea belcheri, C. gigas and Saccostrea commercialis. In: The 13th Annual Conference: Field of Animal Science and Fisheries, Lampang. (Thailand), 13: 24-26.

Lam, K. and Morton, B. 2003. Mitochondrial DNA and morphological identification of a new species of Crassostrea (Bivalvia: Ostreidae) cultured for centuries in the Pearl River Delta, Hong Kong, China. Aquaculture 228: 1-13.

Lapegue, S., Boutet, I., Leitao, A., Heurtebise, S., Garcia, P., ThiriotQuievreux, C. and Boudry, P. 2002. Trans-Atlantic distribution of a mangrove oyster species revealed by $16 \mathrm{~S}$ mtDNA and karyological analyses. Biol. Bull. 202: 232-242.

Leitao, A., Boudry, P., Labat, J. and Thiriot-Quievreux, C. 1999a. Comparative karyological study of cupped oyster species. Malacologia 41: 175-186.

Leitao, A. and Chaves, R. 2008. Banding for chromosomal identification in bivalves: A 20-year history. Dyn. Biochem. Process Biotechnol. Mol. Biol. 2: 44-49.

Leitao, A., Chaves, R., Santos, S., Boudry, P., Guedes Pinto, H. and Thiriot-Quievreux, C. 2002. Cytogenetic study of Ostrea conchaphila (Mollusca: Bivalvia) and comparative karyological analysis within Ostreinae. J. Shellfish Res. 21: 685-690.

Leitao, A., Thiriot-Quievreux, C., Boudry, P. and Malheiro, I. 1999 b. A 'G' chromosome banding study of three cupped oyster species: Crassostrea gigas, Crassostrea angulata and Crassostrea virginica (Mollusca: Bivalvia). Genet. Sel. Evol. 31: 519-527.

Li, X. and Havenhand, J. 1997. Karyotype, nucleolus organiser regions and constitutive heterochromatin in Ostrea angasi (Molluscae: Bivalvia): Evidence of taxonomic relationships within the Ostreidae. Mar. Biol. 127: 443-448.

Martinez-Exposito, M. J., Pasantes, J. J. and Mendez, J. 1994. NOR activity in larval and juvenile mussels (Mytilus galloprovincialis Lmk.). J. Exp. Mar. Biol. Ecol. 175: 155-165.

Moynihan, E. P. and Mahon, G. A. T. 1983. Quantitative karyotype analysis in the mussel Mytilus edulis L. Aquaculture 33:
301-309.

Patakine Varkonyi, E., Urbanyi, B. and Glamuzina, B. 2013. Karyological study reveals a putatively distinctive population of the European flat oyster (Ostrea edulis) in Mali Ston Bay, Croatia. Acta Adriat. 54: 111-116.

Pereira, J. C., Chaves, R., Batista, F. M., Guedes-Pinto, H. and Leltao, A. 2011. Cytogenetic characterization of the dwarf oyster, Ostrea stentina (Mollusca: Bivalvia) and comparative karyological analysis within Ostreinae. J. Shellfish Res. 30: 211-216.

Sangpakdee, W., Phimphan, S., Tengjaroenkul, B., Pinthong, K., Neeratanaphan, L. and Tanomtong, A. 2017. Cytogenetic study of tree microhylid species (Anura, Microhylidae) from Thailand. Cytologia 82: 67-74.

Suzana, M., Mohd Lutfi, A., Abdul Hadi, A., Devakie, M. N. and Siti Azizah, M. N. 2011. Genetic variation in Malaysian oysters: Taxonomic ambiguities and evidence of biological invasion. Biol. Invasions 13: 1893-1900.

Thiriot-Quiévreux, C. 2002. Review of the literature on bivalve cytogenetics in the last ten years. Cah. Biol. Mar. 43: 17-26.

Thiriot-Quiévreux, C. and Insua, A. 1992. Nucleolar organiser region variation in the chromosomes of three oyster species. J. Exp. Mar. Biol. Ecol. 157: 33-40.

Visootiviseth, P., Day, A. and Siwadune, T. 1998. Electrophoretic and morphometric analyses in species differentiation of small Oysters, Saccostrea spp., in Thailand. J. Sci. Soc. Thailand 24: 24-36.

Yoosukh, W. and Duangdee, T. 1999. Living Oysters in Thailand. Res. Bull. Phuket Mar. Biol. Cent. 19: 363-370.

Wang, Y., Xu, Z. and Guo, X. 2004. Differences in the rDNA-bearing chromosome divide the Asian-Pacific and Atlantic species of Crassostrea (Bivalvia, Mollusca). Biol. Bull. 206: 46-54.

Xu, Z., Guo, X., Gaffney, P. and Pierce, J. 2001. Chromosomal location of the major ribosomal RNA genes in Crassostrea virginica and Crassostrea gigas. Veliger 44: 79-83. 